\title{
APPLICATION OF THE ETHICS CODE AND RULES OF PROFESSIONAL CONDUCT OF ACCOUNTS AND AUDITORS
}

\author{
Zoran Todorovic \\ University Mediterranean, Faculty for business studies, "Montenegro \\ Business School", Podgorica, Montenegro
}

OMESTE

JEL Category: H83, M41, M42

\begin{abstract}
The basic task of the Accountants and Auditors is to collect, arrange and present the information to the interested parties in form of accounting or audit reports. Reliable and transparent financial reporting, which results in true and fair presentation of the financial performance of companies, is an important determinant of the financial system reliability and stability. The high level of confidence in the quality of information shown in financial statements increases the security of investors, encourages new investments, accelerates the financial and trade flows and increases the efficiency of capital markets and the economy as a whole. Huge financial frauds and financial crisis led to high distrust in the accounting profession. Returning lost credibility is possible only if professional accountants and other participants in the process of financial reporting provide services to the highest ethical requirements. The efforts of the accounting profession are undeniable to respond to the changed requirements of the users of the financial statements, to create a normative basis, the application of which will provide quality financial reporting
\end{abstract}

Keywords: quality of financial reporting, accounting, ethics, public interest, confidence, responsibility

\section{INTRODUCTION}

Today, it is clear to everyone that the accounting profession must prioritize the public interest and take responsibility for protecting that interest in the field of financial reporting. The accomplishment of a Public Interest Guard mission implies the existence of a transparent reporting system that will minimize information risks by minimizing the risk of disclosure of business-financial risks.

\footnotetext{
Address of the author:

Zoran Todorović

㫪”: zorannt@t-com.me
}

The low level of confidence in the financial reporting system discourages investors, increases their prudence, and slows down the financial flows, which results in a reduction in the efficiency of the capital market and the economy. Since the consequences of wrong information signals from non-performing financial reports are very unpleasant, the public, in the broadest sense, expects the accounting profession to perform entrusted duties, adhering to the highest professional standards in the provision of public interest.

Never in its history until the last 10 years, financial reporting has not generated such a great interest 
of the general public. Certain financial scandals, which were followed by frauds in the financial statements, from the end of the previous and the beginning of this century, certainly contributed to this. For years, he has built a reputation, he fell to the lowest levels precisely because of the threat of public interest. Confidence, security, and optimism built on it have been replaced by mistrust, fear, and skepticism.

In addition to efforts aimed at improving legal and professional regulations, raising the quality of corporate governance and setting up independent public oversight bodies, ensuring high-quality financial reporting entails compliance with high ethical requirements. We believe that today, when the pressures on the accounting profession and the expectations from it are greatest, and the trust of the investment public at least, there is no other way but to ensure that financial reporting is reliable and transparent and that the financial statements are fairly audited. There is no other way to regain lost public trust.

This research aims to find out whether companies in Montenegro apply and follow the code of ethics and professional conduct of accountants and auditors and does the size of the company has any influence on the application of abovementioned codes. Statistical techniques used in the analysis of the results of the empirical research were selected in accordance with the nature of the data collected, the method of measurement and the nature of the variable and set objectives of the research.

\section{ETHICS - CONCEPT, ETHICAL DECORATION AND ETHICAL CHALLENGES ACCOUNTING AND AUDITORS}

\subsection{The notion of ethics}

Ethics (Greek Ethos = custom, usage, miracle) is defined as a set of habits, the rule of a person, a nation or a class. Ethics predominantly signifies a set of principles, rules, and morals, and also the science of morality; (philosophy of morality), which explores the meaning and goals of moral norms, the basic criteria for moral evaluation, as well as the generality and source of morality in general (Krasniqi, 2006).
In particular, in this case, we can talk about the rules that are being set for and before the auditors.

The widespread use of financial information and a high level of accountability in accounting for the public interest raise the quality of financial reporting to the highest level in the accounting profession's prioritization scale. Capitalization of individual expenditures or, alternatively, their inclusion in the profit and loss account, valuation of property and equipment, and related life-cycle choices and write-off methods, valuation of inventories by applying the purchase price, cost price or lower value principle, postponement or acceleration of write-off of receivables, formation or elimination of long-term provisions and their more or less conservative estimate, different balance sheet treatment of business and financial leasing, etc. are just a few examples of possible impacts within the allowed scope of recruiting business results between different accounting periods, and consequently on the current and future profitability and financial position of the company (Stickney, Brown, \& Wahlen, 2007).

Low level of confidence in the financial reporting system discourages investment, increases the degree of their caution, and slows down financial flows, which results in a reduction in the efficiency of the financial markets and the economy as a whole.

\subsection{Ethical judgment as a determinant of the quality of financial reporting}

We have seen that the financial reporting system, due to the scope and importance of the information it offers, its public character and its role in preserving the public interest, plays a key role in the information service of investors and other interest groups, the improvement of investor protection, the establishment of trust in the capital market and the provision of stability financial system.

Additional security for external users in terms of the quality of information in the financial statements should be provided by independent external auditors through credible assurances as to whether and to what extent financial statements are compiled in accordance with the relevant reporting rules. 
Responsibility for the quality of financial reporting is facing great challenges. On a global level, they are international organizations and bodies, the International Organization of Securities Commissions (IOSCO), the International Federation of Accountants (IFAC) and the International Accounting Standards Board (International Federation of Accountants - IASB), at the national level, they are the state, national regulatory bodies, professional organizations and independent public supervisory bodies, while at the company level the responsibility rests with management, auditing committee and professional accountants (including auditors).

Among other things, common to all scams is the lack of ethics. One part of accounting fraud resulted from a direct violation of legal and professional regulations. In these circumstances, the situation is all the more simplistic, as the consequences for the participants of such processes are clear. It seems to us that the situation is more complex when accounting manipulations arise as a result of the misuse of the inconsistency of the relevant regulation or the flexible interpretation of existing norms for the purpose of achieving benefits for particular interest groups. In this context, ethics in accounting could be presented as a set of widely accepted moral norms and values that professional accountant's serve as guides in the process of ensuring the required quality of financial reporting and responsible execution of the role of "guardians" of the public interest. Laws, that is, professional and legal regulations in accounting create minimum standards of acceptable behavior. Ethics goes beyond the law and covers all those situations that are not covered by legal and professional norms, all those unclear cases, and so on. Legal gaps (Minz \& Morris, 2008). Standards of ethical behavior narrow down space for activities that are not in accordance with moral norms.

The lines of demarcation between ethical and non-ethical may be insufficiently clear. Issues related to valuations, balancing of profits, determining the expenditure capitalization measure, formation of reserves and latent reserves, volume and quality of disclosure, and many others can have more responses. Ethics is actually necessary for such situations when we have more answers.

Recognizing the size and seriousness of the problem, the accounting profession has, like many others, established the Code of Ethics for Professional Accountants, adopted by the IFAC International Standards Ethics Committee, obliging member organizations of IFACs and companies not to apply standards that are less demanding of those prescribed by this document. Professional accountants are required to recognize threats of possible violation of these principles and to apply safeguards if such threats exist to ensure compliance with the underlying principles.

Josephson Institute of Ethics has identified six pillars of character that provide the basis for moral decision-making by professional accountants. These are (Association of Accountants and Auditors of Serbia, 2016):

- Trustworthiness, which includes honesty, integrity, reliability, and loyalty in relationships with others,

- $\quad$ respect, which, in dealing with others, implies courtesy, kindness, competence, dignity, independence, tolerance and acceptance,

- Responsibility, which means expressing a certain level of care and diligence in what we do,

- Fairness, which presupposes the treatment of all people in the same way, impartially and openly,

- Caring, in terms of the ability to understand the interests and problems of others, which Josephson considers the heart of ethics and moral decision-making, and

- The duty of a good citizen, which implies behavior as a good member of the community.

Everything is necessary before, but the question is how to encourage it all. Improvements in this plan assume activities in two directions. First, efforts should be made in the development of personal development, which implies broad education, further training through various forms of continuous education, and reading of the literature on ethics, as well as fostering a commitment to work and high opinion of the profession. The second direction is fostering a corporate culture in companies that support ethics 
and professionalism and where examples of ethical behavior of superiors and elders represent signs for subordinates and young people.

\subsection{Ethical challenges of accountants in the process of applying accounting regulations}

The confidence crisis in the accounting profession is caused by the inadequate behavior of different participants in the financial reporting chain. It was created and survived as a result of the inability to solve an agency problem, the existence of a conflict of interest in management and auditors, the inability of the accounting profession to solve some problems in reporting quickly, efficiently and in the long run. It must be acknowledged, however, that the current crisis of confidence is certainly a consequence of the lack of ethics in the behavior of almost all participants in the financial reporting chain.

In addition, the high intensity of changes in the environment, new business ideas and the development of a whole range of new financial instruments have caused the pace of changes in accounting standards to be very fast. This causes more problems.

First, the effort to put accounting rules in line with specific situations, instead of emphasizing more emphasis on principles, results in the development of often too complex solutions that complicate their application in practice.

Second, changes in accounting rules under pressure are often not good and have a short-term character.

Thirdly, a large volume of accounting standards, rapid and frequent changes in them make it impossible for an accounting profession, represented by professional accountants and auditors around the world, to monitor and apply standards in a quality way.

The fourth, occasional change in the way in which individual balance sheet positions are included in the balance sheets threatens comparability as a quality that makes information useful to investors. If comparators do not have investors, as key users of accounting information, they do not feel safe enough to use them. All of this seems to us to expand the maneuvering space for a possible impact on the design of the company's performance, contributing to the uncertainty and uncertainty in the application of regulations, making ethical behavior inevitable and urgent.

Ethical behavior implies true and fair reporting, which includes the complete disclosure of relevant information (the Association of Accountants and Auditors of Serbia, 2016). It is impermissible to create hidden losses and deliberately distorts the content of the financial statements.

It is certain that aggressive behavior leads to an increase in information risks and distances from a realistic idea of the true performance of the company. The admissibility of fair values for the valuation of individual property parts, for example, is calculated to increase the relevance of information. Fair value should reflect the economic reality, but due to the wide maneuvering space left to managers and accountants, especially in the conditions of illiquid markets, the reliability of the report again depends on the ethical understanding of true and fair reporting.

There are also many other reporting challenges: selecting the moment of recognition of unrealized gains, capitalizing or not capitalizing expenditures, aggressive or moderate write-off policy, respecting reasonable measures to allocate costing costs, selecting the cost of the cost price to evaluate the stock of effects, duplicating the real ones out of the contingent liabilities, business-to-business activities, the movement of cash flows between business and investment activities, etc. Detailed disclosures of the applied accounting policies, which, among other things, indicate the manner and effects of asset valuation, the disclosure of the structure of financial placements, the structure and quality of receivables, the structure and maturity of liabilities, and the like. Provide an opportunity to assess the quality of financial statements. Even when some more aggressive valuation methods in balance sheets and success are applied, if their application and effects on results and financial structure are fully disclosed, then this can significantly reduce information risks (Reilly \& Brown, 2003). In practice, it often happens that users of information easily pass over the remarks, which is a big mistake. 


\subsection{Ethical challenges in auditing practice}

The main purpose of the audit is to provide reasonable assurance whether the company's financial statements are compiled in accordance with relevant professional and legal regulations, or whether the financial statements in a true and fair manner reflect the performance of the company.

Management, whose accomplishments are assessed on the basis of information in the financial statements, is actively involved and is ultimately responsible for the preparation of these reports. In such conditions, maintaining confidence in financial reporting implies an impartial opinion on the quality of the report. In this context, an independent audit is an integral part of the public interest system.

Independence of the auditor is one of the pillars of the existence of an accounting profession. In doing so, the task of an accountant is to create truthful and honest reports on the success and financial position of the company, primarily to the investment public who rely on the information process in the decision-making process. The task of the auditor, who is the first accountant and then the auditor, is to provide credible assurances to users of information, again primarily to investors, with their independent opinion on whether the financial statements have been compiled in accordance with relevant legal and professional regulations, or whether they are true and honest They represent the success and financial position of the company.

In its ruling, in the case of Arthur Young \& Co., the US Supreme Court unambiguously confirmed the primacy of public accountability and the need to preserve independence. It is clearly stated in the judgment that by confirming public reports, which summarize the financial status of a corporation, the independent auditor assumes a public responsibility that exceeds any liability in relation to the client.

It is this specific position of the auditor that is the source of many troubles for investors, auditors and the entire accounting profession. The key danger is a loss of independence. Fear in this regard is due to the existence of a latent conflict of interest, pressure exposures, and provision of non-audit services and inadequate control of the work of auditors.

First, the auditors, by the nature of the relationships that exist in relation to "company management - auditor - investment public", are always in conflict with interns. In this context, the auditor is in a very unfavorable position. The fact is that management engages, releases and pays auditors. By giving him a job, management enables auditors to earn a living, but the responsibility of the auditor in the public interest requires that he provides services to investors and other external users. The management objective is to comply with the requirements of the regulatory bodies, to gain a positive opinion and to safeguard investor confidence.

Additionally, loss of clients due to an opinion that does not satisfy the management can be negatively reflected in the career of individual auditors, which is why they can endeavor to avoid the dissatisfaction of the management.

Secondly, auditors are often exposed to various pressures. They are pressed by deadlines, which can be very short in relation to the complexity of work. This encourages behavior where the quality of the audit is not the primary source of income, but the number of audits carried out, which interests the interests of investors and the interests of the accounting profession to the other. Auditors are also under pressure that their opinion depends on the possibility of acquiring new capital for the company in the coming periods, the movement of stock prices, and sometimes the survival of the company.

In addition to the previous one, auditors are also exposed to pressures related to the fear of a possible legal dispute due to the insufficient good understanding of the problem and wrong conclusions in the opinion. Collective litigation represents a major burden for auditing firms. Eventual loss of litigation triggers the right to compensate, which can lead to auditing firms in serious financial problems.

Third, non-audit services pose a major threat to the independence of the auditor. Regardless of the fact that arguments that support the provision of audit and non-audit services to the same client (better acquainting enterprises and higher quality audits), non-audit services are a serious warning 
signal for the analysis of the financial reporting quality and the quality of the audit performed. Non-audit services can be used to would be compensated for the low cost of auditing services.

To this we must add that increased competition between the auditor and the "hijacking" prices may be the reason for reducing the auditor's attention and therefore the quality of audit opinion (Crane \& Matten, 2004). All this, all the more so before in the audit services market I can almost always find companies that offer "more liberal" interpretation of regulations.

Fourth, the control of the work of auditors by different professional associations is not effective enough. Again, this is a classic conflict of interest, which is now a consequence of the closeness of such associations with auditors and audit firms. We have already mentioned that practice has shown that self-regulation and self-review are not sufficient. This had the effect of shifting to.

\subsection{Dilemmas regarding ethical behavior}

Accounting ethics become part of the everyday business; therefore, if it wants to be successful in its work, ethics should not be separated from profitability, but by establishing codes of ethics and socially responsible behavior, ethical attitudes and beliefs should be aimed at the common goal of development and growth.

Professional ethical principles to be applied to financial reporting are based on:

- the choice of quality moral qualities,

- then on the choice of knowledge related to performing the profession,

- using that knowledge in objective judgment and conclusion,

- proven trust and

- The requirement for professional behavior.

The consequences of non-performing financial reporting can be serious:

- because they do not affect only the owners of the company due to loss of expected dividend yields and capital gains,

- but also, for employees because of a possible reduction in wages,

- to the capital market because there is distrust,

- to the state because of evasion of taxes,
- to lenders due to loss of interest and capital, - to the national economy as investments and gross domestic product are reduced, unemployment is growing, - even on the accounting profession itself, because credibility is undermining.

\section{Unethical behavior in the accounting profession}

Accounting data manipulated by individuals within the company is misleading in a way that they do not want to be deceived. This is about trust, conflict of interest, confidentiality of information, and whistleblowing.

Whistling is the process of individuals directed to public warning of illegal or unethical business activities, regardless of the consequences that they may face due to such actions. In accordance with the principle of prudence, it is important to keep in mind that under conditions of uncertainty, losses are not underestimated, and the profits are not overestimated.

Sometimes, in order to fulfill the demands of the superiors, it passes through defective and dubious accounting operations such as tax fraud, adjustment of the business result, incorrect accounting. The main driver of unethical behavior most often lies in the efforts:

- towards greater ambition, resulting in an increase in most cases of personal gain

- or because of pressure from the superiors to achieve positive financial results in a shorter period.

Looking at the global decline in confidence in financial reporting is:

- generally, increases the investment risk for investors,

- financial flows slow down,

which ultimately affects the reduction of the efficiency of the capital market

Why and how does it behave in the pursuit of an ethical conflict during the performance of a professional accountant?

Considering the key role that due to the nature of the work due to the relationship with the employer and / or the client, but also because of the attitude towards the general public, and beyond the interest of financiers, creditors and potential investors, the full and consistent application of its 
ethical code for every professional accountant is also basic it is crucial that no ethical conflict should be concealed and must be resolved. In this connection, first attempts to clear the conflict problem with the direct superior, and if this is not successful at all the existing following control levels to the highest. If this fails, it is consulted in a confidential manner with an independent counselor and/or with a competent authority within a professional organization to which an accountant belongs to a participant in an ethical conflict. If even this does not lead to the overcoming of an ethical conflict such an accountant, convinced of the correctness of his or her point of view, he may choose to terminate with the appropriate written explanation.

In addition, when it comes to employment in accounting or the provision of services outside the country of the parent, and there are differences between these two countries, the ethical principles are the rule that the ethical principles that are more stringent.

Why there are additional guidelines regarding the respect and application of professional ethics by accountants who practice public practice and who are?

Because every professional accountant is expected to make his annual accounting statements, or in general his financial statements, true and fair, while a professional accountant in public practice should, through his / her opinion, convincingly determine whether this is and how much. For such a thing in addition to the level of education, which is below the usual for other professional accountants, including all that provided for in the Code of Conduct for Accountants in connection with the performance of public practice and a specific relevant experience, it is of utmost importance that a complete and consistent fulfillment of everything that convincingly ensures the real independence.

Additional guidelines for professional accountants who perform public practice, primarily for certified accountants, are:

- Independence from the point of view of financial relationships with clients and employees in companies;

Independence from the point of view of personal and family connections related to audit services to clients;
Independence from the point of view of payment of compensation and/or receipt of goods and services;

Independence from the point of view of equity in the audit firm to which it belongs;

- Liability towards clients in connection with fees and/or commissions in connection with them;

- Responsibility towards clients in relation to keeping their money and managing them;

- Responsibility to other professional accountants who perform public practice and in general professional accountants in relation to professional mutual relations;

- Responsibility to other professional accountants who perform public practice in connection with advertising;

- The responsibility of a professional accountant performing public practice in relation to his comparative activities that are incompatible with the practice and reputation of the profession

Additional guidelines for professional accountants emphasize independence as a necessary first prerequisite for conducting public practice by a professional accountant. While this is completely clear, there is an objective problem that in different countries is treated differently or more in different ways to ensure independence. The most important differences arise whether this, in addition to the provisions of professional accounting regulations, is regulated by the state and then sanctioned accordingly if it is violated by the competent state authority. In addition, it implies that the precondition and essential independence must be fulfilled, whether they appear or appear to be independent.

Whether there is substantial independence depends on the factual fulfillment of concrete conditions, that is, there is evidence to be appreciated, that is, it makes or strengthens or weakens of it. However, the phenomenon of independence is the created impression of the client, other interested parties and the public in general whether and how individual professional accountants performing public practice are independent, and such a view in relation to the whole of this segment of the accounting profession. 
Substantial independence strengthens the rotation of an authorized accounting auditor after several consecutive years, thus achieving not only too much intimacy between them and the client, but also the insight of another independent certified accounting auditor in the performance of its predecessor. Then, in the total revenue of an auditing accounting firm, the participation of any individual client would have to be as much as approximately, i.e. nobody is significantly more significant and prevailing, thus avoiding possible dependence, including from the loss of an individual client. It is also important to monitor the quality of the service provided by an independent certified accounting auditor, and whether it is and how much it is capable of coping with a more sophisticated client's technical and technological environment.
In the end, the independence of the provision of services by a professional accountant performing public practice is undoubtedly strengthened by limiting only to this service, or by denying other services to the same client.

\section{RESEARCH RESULTS}

Based on presented theoretical overview, for this research two hypotheses have been created:

1. The company has a code of ethics

2. The implementation of the code depends on the size and activities of a legal entity

The research was conducted on employees in different legal subjects in Montenegro by the way of online and paper surveys. The results were analyzed in statistical package SPSS. The sample consists of 83 observations, and its structure is given in table 1 .

Table 1. Division of enterprises by activity

\begin{tabular}{|l|r|r|r|r|}
\hline \multicolumn{1}{|c|}{ Valid } & Frequency & Percent & Valid Percent & Cumulative Percent \\
\hline Bank & 5 & 6.0 & 6.0 & 6.0 \\
\hline Budget Institution & 8 & 9.6 & 9.6 & 15.7 \\
\hline Other & 37 & 44.6 & 44.6 & 60.2 \\
\hline Insurance organization & 5 & 6.0 & 6.0 & 66.3 \\
\hline Production & 10 & 12.0 & 12.0 & 78.3 \\
\hline Commercial & 18 & 21.7 & 21.7 & 100.0 \\
\hline Total & 83 & 100.0 & 100.0 & - \\
\hline
\end{tabular}

Almost half of the respondents (44.6\%) are employed in other legal entities predominantly in limited liability companies, followed by trade companies $(21.7 \%)$ and manufacturing companies $(12.0 \%)$. The smallest number of respondents are employed in banks $(5.0 \%)$, as well as in insurance organizations (5.0\%).

Table 2. Division of enterprises by size

\begin{tabular}{|c|r|r|r|r|}
\hline Valid & Frequency & Percent & Valid Percent & Cumulative percent \\
\hline Small Company & 50 & 60.2 & 60.2 & 60.2 \\
\hline Medium Company & 20 & 24.1 & 24.1 & 84.3 \\
\hline Large Company & 13 & 15.7 & 15.7 & 100.0 \\
\hline Total & 83 & 100.0 & 100.0 & - \\
\hline
\end{tabular}

The largest number of respondents are employed in small legal entities (60.2\%), followed by medium-sized legal entities $(24.1 \%)$ and large legal entities (15.7\%). The mentioned representation of legal entities by size in the sample corresponds to the structure of legal entities by size in Montenegro (Monstat, 2016). 
Table 3. Structure of the answer to the question of having a code of ethics

\begin{tabular}{|l|r|r|r|r|}
\hline Valid & \multicolumn{1}{|c|}{ Frequency } & \multicolumn{1}{c|}{ Percent } & Valid Percent & Cumulative Percent \\
\hline No answer & 1 & 1.2 & 1.2 & 1.2 \\
\hline Yes & 51 & 61.4 & 61.4 & 60.7 \\
\hline No & 24 & 28.9 & 28.9 & 91.6 \\
\hline Not Sure & 7 & 8.4 & 8.4 & 100.0 \\
\hline Total & 83 & 100.0 & 100.0 & - \\
\hline
\end{tabular}

The majority of respondents answered that they respondents' answers that they do not possess had a code of ethics $(61.4 \%)$, followed by ethical codes $(28.9 \%)$ and are not sure $(8.4 \%)$.

Table 4. The opinion that ethics is a non-formal subject for studying at faculties

\begin{tabular}{|l|r|r|r|r|}
\hline Valid & Frequency & Percent & Valid Percent & Cumulative Percent \\
\hline Yes & 71 & 85.5 & 85.5 & 85.5 \\
\hline No & 2 & 2.4 & 2.4 & 88.0 \\
\hline Not Sure & 10 & 12.0 & 12.0 & 100.0 \\
\hline Total & 83 & 100.0 & 100.0 & - \\
\hline
\end{tabular}

Most respondents answered that business ethics are a necessary subject for faculty education (85.5\%), followed by respondents' answers that it is not a necessary subject for faculty education $(2.4 \%)$ and we are not sure $(10.0 \%)$.

Table 5. Structure of the answer to the question of adherence to the principles of the Code of Ethics

\begin{tabular}{|l|c|c|c|c|}
\hline Valid & Frequency & Percent & Valid Percent & Cumulative Percent \\
\hline No answer & 2 & 2.4 & 2.4 & 2.4 \\
\hline Yes & 66 & 79.5 & 79.5 & 81.9 \\
\hline Partly & 13 & 15.7 & 15.7 & 97.6 \\
\hline No & 2 & 2.4 & 2.4 & 100.0 \\
\hline Total & 83 & 100.0 & 100.0 & - \\
\hline
\end{tabular}

To question Are you complying with the principles of the Code of Ethics for professional accountants in accounting? most respondents answered that they adhered to the Code of Ethics (79.5\%), followed the responses to partially adhere (15.7\%) and did not abide by $(2,4 \%)$.

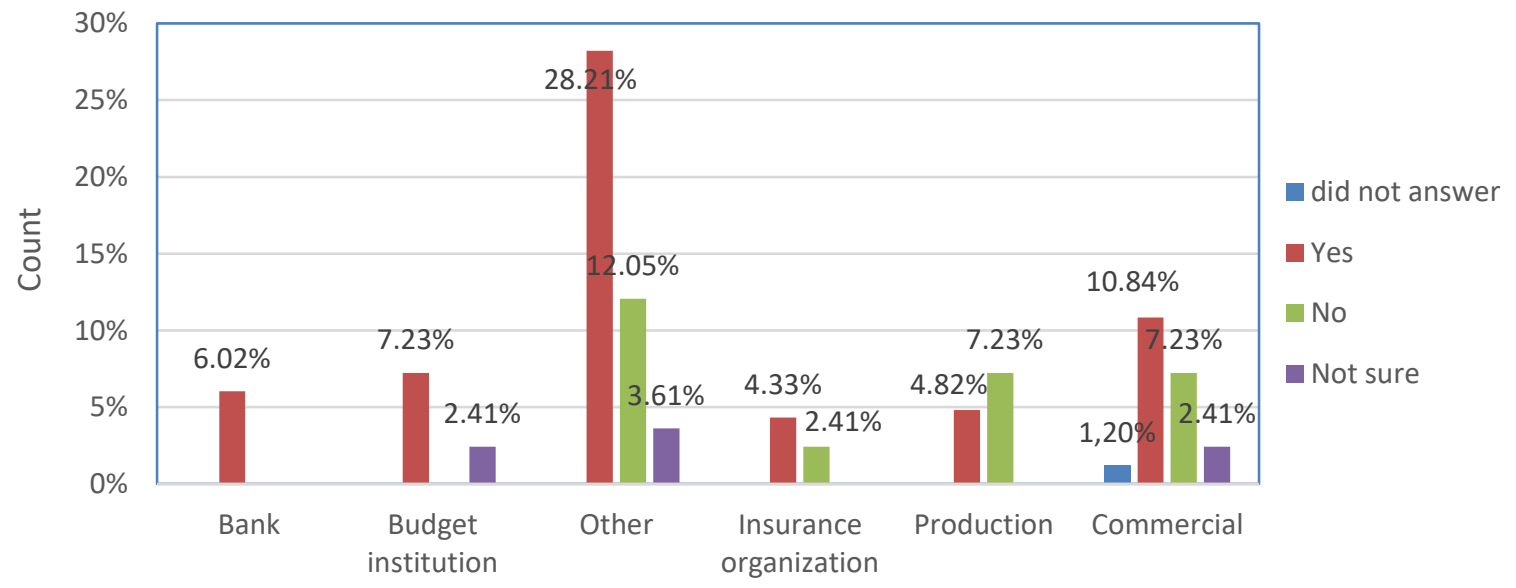

Figure 1. The structure of the answer to the question "The company in which I work has a Code of ethics?" according to the company's business 


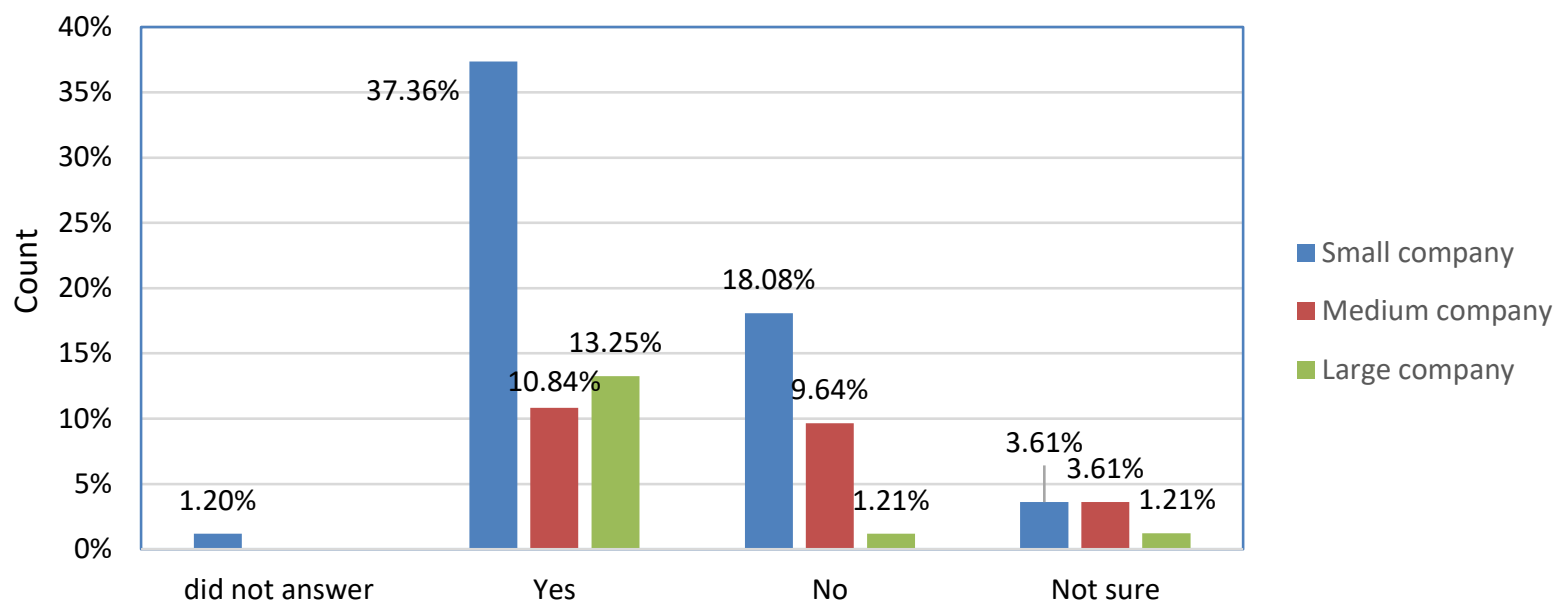

Figure 2. The structure of the answer to the question "The company in which I work has a Code of ethics?" by company size

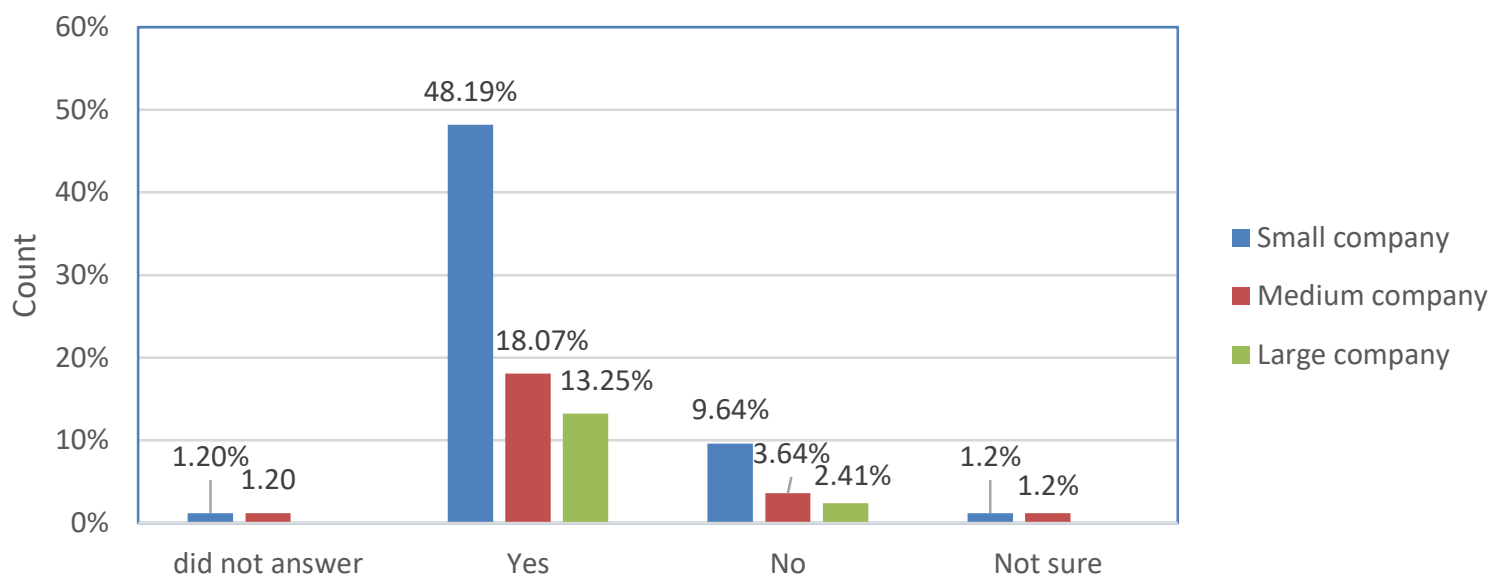

Figure 3. The structure of the answer to the question: "Are you complying with the principles of the Code of ethics for professional accountants when conduction accounting work?

Viewing the answer to the question of whether the company has a code of ethics according to the size of the company:

The answer to the question of whether you adhere to the principles of the Code of Ethics for professional accountants when performing accounting is shown by the size of the company:

\section{INTERPRETATION OF RESULTS AND HYPOTHESIS TESTING}

For each variable, the percentage of data is missing, and cross-tabulation (Crosstabs) is established between the variables. Finally, the relationship between the observed variables was investigated using the Chi-square test of independence (Pearson's Chi-Square), while the degree of association was estimated using Kramer's V (Cramer's V).

The results of the Chi-square test show that there is a statistically significant difference at $p<0.05$ between the presented groups of subjects in the sample regarding the level of application of the code of ethics. To make the result significant, the approximate probability (Asymptotic Significance) should be 0.05 or less. In this example, this value is greater than the alpha value of 0.05 , so we conclude that our result is not significant. However, a possible limitation may be due to the fact that one of the hypotheses of the Chi-square test has been violated in terms of the least expected cellular frequency, which should be 5 or more. 
Does the company have a code of ethics depends on the activity and size of the legal entity, as the size of the sample taken?

\section{CONCLUSIONS}

Professional and legal regulations represent minimum standards of behavior, not only professional accountants but also all those involved in the quality assurance process of financial reporting. Ethics builds on them and provides guidance for the behavior of all participants in the process.

Since there is considerable room for judgment in accounting regulations, decisions are often made in situations where the rules are not clear enough and the line of delimitation between what is acceptable and what is not acceptable is not always easy to withdraw, accounting is considered one of the most ethically demanding profession. Bearing in mind that the chain of participants in the financial reporting process is long and that there are important non-calculators in this chain, all participants in this process must comply with the standards of ethics in accounting.

Strong pressures by the owner to achieve the highest results, demonstrate a more favorable picture of company achievements that will leave a strong impression on existing and potential shareholders, facilitate the negotiating position with lenders and strengthen management positions, turning conservative, true and fair reporting into an aggressive and "creative" accountants, often ready to design performance in accordance with individual goals, which forgets their role in serving the public interest. The space for various creations in the financial statements is so broad that the behavior of managers and accountants in the financial reporting process is a first-class ethical issue.

In this context, ethical challenges of accountants in areas of direct accounting, ethical challenges that lie ahead of management, ethical challenges in the area of auditing practice, ethical challenges at the legislative level where appropriate regulation is created, as well as ethical challenges associated with majority owners, financial and legal advisors, political elites and academic accountants, can be a topic for discussion.

Insisting on the attitude of the auditors that are contrary to the interests of the management carries with it the risk of losing the job. On the other hand, the fact that the cost that results from the unethical behavior of individuals is negligible compared to the damage done to the profession must always be in our minds.

Therefore, in order to regain the lost trust of the profession, it must build its reputation on the basis of ethics and honesty.

\section{WORKS CITED}

Crane, A., \& Matten, D. (2004). Business Ethics: A European Perspective. New York: Oxford University Press.

Krasniqi, J. (2006). Kodeks profesionalne etike. Zagreb .

Minz, S., \& Morris, R. (2008). Ethical Obligations and Decision Making in Accounting, Text, and Cases. New York: McGraw Hill.

Reilly, K., \& Brown, C. ( 2003). Investment Analysis \& Portfolio Management. Mason, Ohio: Thomson.

Savez racunovodja i revizora Srbije. (2016). Eticki kodeks za profesionalne racunovodje : Medjunarodni standardi i saopstenja revizije, uveravanja i etike, prevod. 113-124. Beograd: Savez racunovodja i revizora Srbije.

Stickney, C., Brown, P., \& Wahlen, J. ( 2007). Financial Reporting, Financial Statement Analysis, and Valuation - A Strategic Perspective. Mason, $\mathrm{OH}$ 45040, USA: South-Western Cengage Learning. 
Attachment 1. The existence of the Code of Ethics by type of enterprise

\begin{tabular}{|c|c|c|c|c|c|c|c|}
\hline \multirow{2}{*}{\multicolumn{3}{|c|}{$\begin{array}{l}\text { 1. The company you are at * } 4 \text {. The company in which I } \\
\text { work, has a Code of Ethics? }\end{array}$}} & \multicolumn{4}{|c|}{$\begin{array}{c}\text { 4. The company in which I work, } \\
\text { has a Code of Ethics? }\end{array}$} & \multirow{3}{*}{$\begin{array}{c}\text { Total } \\
5\end{array}$} \\
\hline & & & \multirow{2}{*}{$\begin{array}{c}\text { No answer } \\
0\end{array}$} & \multirow{2}{*}{\begin{tabular}{|c|} 
Yes \\
5
\end{tabular}} & \multirow{2}{*}{$\begin{array}{c}\text { No } \\
0\end{array}$} & \multirow{2}{*}{\begin{tabular}{|c|}
$\begin{array}{c}\text { Not } \\
\text { Sure }\end{array}$ \\
0 \\
\end{tabular}} & \\
\hline \multirow{18}{*}{ 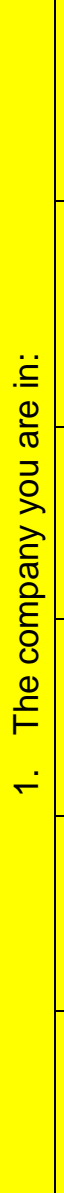 } & \multirow{3}{*}{ Bank } & count $^{2}$ & & & & & \\
\hline & & $\%$ within 1 . The company you are in: & $0.0 \%$ & $100 \%$ & $0.0 \%$ & $0.0 \%$ & $100 \%$ \\
\hline & & $\begin{array}{c}\text { \% within } 4 . \text { The company in which I } \\
\text { work, has a Code of Ethics? }\end{array}$ & $0.0 \%$ & $9.8 \%$ & $0.0 \%$ & $0.0 \%$ & $6.0 \%$ \\
\hline & \multirow{3}{*}{$\begin{array}{l}\text { Budget } \\
\text { institution }\end{array}$} & count & 0 & 6 & 0 & 2 & 8 \\
\hline & & $\begin{array}{l}\% \text { within } 1 . \text { The company you are } \\
\text { in: }^{3}\end{array}$ & $0.0 \%$ & $75.0 \%$ & $0.0 \%$ & $25.0 \%$ & $100 \%$ \\
\hline & & $\begin{array}{c}\text { \% within } 4 . \text { The company in which I } \\
\text { work, has a Code of Ethics? }\end{array}$ & $0.0 \%$ & $11.8 \%$ & $0.0 \%$ & $28.6 \%$ & $9.6 \%$ \\
\hline & \multirow{3}{*}{ Other } & count & 0 & 24 & 10 & 3 & 37 \\
\hline & & $\%$ within 1 . The company you are in: & $0.0 \%$ & $64.9 \%$ & $27.0 \%$ & $8.1 \%$ & $100 \%$ \\
\hline & & $\begin{array}{c}\text { \% within } 4 . \text { The company in which I } \\
\text { work, has a Code of Ethics? }\end{array}$ & $0.0 \%$ & $47.1 \%$ & $41.7 \%$ & $42.9 \%$ & $44.6 \%$ \\
\hline & \multirow{3}{*}{$\begin{array}{l}\text { Insurance } \\
\text { Organization }\end{array}$} & count & 0 & 3 & 2 & 0 & 5 \\
\hline & & $\%$ within 1 . The company you are in: & $0.0 \%$ & $60.0 \%$ & $40.0 \%$ & $0.0 \%$ & $100 \%$ \\
\hline & & $\begin{array}{c}\text { \% within } 4 . \text { The company in which I } \\
\text { work, has a Code of Ethics? }\end{array}$ & $0.0 \%$ & $5.9 \%$ & $8.3 \%$ & $0.0 \%$ & $6.0 \%$ \\
\hline & \multirow{3}{*}{ Production } & count & 0 & 4 & 6 & 0 & 10 \\
\hline & & $\%$ within 1 . The company you are in: & $0.0 \%$ & $40.0 \%$ & $60.0 \%$ & $0.0 \%$ & $100 \%$ \\
\hline & & $\begin{array}{c}\text { \% within } 4 . \text { The company in which I } \\
\text { work, has a Code of Ethics? }\end{array}$ & $0.0 \%$ & $7.8 \%$ & $25.0 \%$ & $0.0 \%$ & $12.0 \%$ \\
\hline & \multirow{3}{*}{ Commercial } & count & 1 & 9 & 6 & 2 & 18 \\
\hline & & $\%$ within 1 . The company you are in: & $5.6 \%$ & $50.0 \%$ & $33.3 \%$ & $11.1 \%$ & $100 \%$ \\
\hline & & $\begin{array}{c}\% \text { within } 4 . \text { The company in which I } \\
\text { work, has a Code of Ethics? }\end{array}$ & $100.0 \%$ & $17.6 \%$ & $25.0 \%$ & $28.6 \%$ & $21.7 \%$ \\
\hline \multirow{3}{*}{\multicolumn{2}{|c|}{ Total }} & count & 1 & 51 & 24 & 7 & 83 \\
\hline & & $\%$ within 1 . The company you are in: & $1.2 \%$ & $61.4 \%$ & $28.9 \%$ & $8.4 \%$ & $100 \%$ \\
\hline & & $\begin{array}{c}\text { \% within } 4 . \text { The company in which I } \\
\text { work, has a Code of Ethics? }\end{array}$ & $100 \%$ & $100 \%$ & $100 \%$ & $100 \%$ & $100 \%$ \\
\hline
\end{tabular}

1 This field indicates which two questions from survey have been put into relation in this cross-tabulation. In this case question no. "1. The company you are in" and question no. "4. The company in which I work, has a Code of Ethics" have been put into relation. In rows are answers for question no.1, while columns present answers for question no.4.

2 Count presents the number of observations per two categories of answers. In this case 5 respondents replayed that work in a bank and that their company has a code of ethics.

${ }^{3}$ This row presents the relative number (percentage) of two categories of answers. In this case $75 \%$ of respondents from budged institutions said that they have code of ethics, while $25 \%$ respondents from same institutions were not sure if they have a code of ethics.

4 This row also presents the relative number (percentage) of two categories of answers but in inverse order from the first one. In this case from all respondents that answered that their company has a code of ethics $11.8 \%$ are from budget institutions, and from all respondents who answered that are not sure that their company has a code of ethic $28.6 \%$ are from budget institutions. 


\begin{tabular}{|c|c|c|c|}
\hline Chi-Square Tests $^{5}$ & Value & Df & $\begin{array}{c}\text { Asymptotic } \\
\text { Signifiance (2-sided) }\end{array}$ \\
\hline Pearson Chi-Square & $6.956^{\mathrm{a}}$ & 6 & .325 \\
\hline Likelihood Ratio & 7.879 & 6 & .247 \\
\hline N of Valid Cases & 83 & - & - \\
\hline
\end{tabular}

a. 7 cells $(58.3 \%)$ have expected count less than 5 . The minimum expected count, $16 .{ }^{6}$

Attachment 2. Owning a code of ethics by company size

\begin{tabular}{|c|c|c|c|c|c|c|c|}
\hline \multirow{2}{*}{\multicolumn{3}{|c|}{$\begin{array}{l}\text { 2. Belongs to the group: * } 4 \text {. The company in which I work, has a } \\
\text { Code of Ethics? }\end{array}$}} & \multicolumn{4}{|c|}{$\begin{array}{l}\text { 4. The company in which I } \\
\text { work, has a Code of Ethics? }\end{array}$} & \multirow{3}{*}{$\begin{array}{c}\text { Total } \\
50\end{array}$} \\
\hline & & & \multirow{2}{*}{\begin{tabular}{|c|}
$\begin{array}{c}\text { No } \\
\text { answer }\end{array}$ \\
1 \\
\end{tabular}} & \multirow{2}{*}{ Yes } & \multirow{2}{*}{ No } & \multirow{2}{*}{\begin{tabular}{|c|} 
Not \\
Sure \\
3
\end{tabular}} & \\
\hline \multirow{9}{*}{ 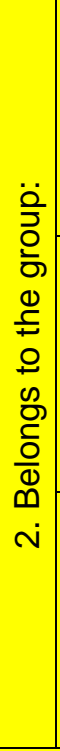 } & \multirow{3}{*}{ Small Company } & count & & & & & \\
\hline & & $\%$ within 2 . Belongs to the group: & $2.0 \%$ & $62.0 \%$ & $30.0 \%$ & $6.0 \%$ & $100 \%$ \\
\hline & & $\begin{array}{l}\% \text { within } 4 . \text { The company in which I work, } \\
\text { has a Code of Ethics? }\end{array}$ & $100 \%$ & $60.8 \%$ & $62.5 \%$ & $42.9 \%$ & $60.2 \%$ \\
\hline & \multirow{3}{*}{ Medium Company } & count & 0 & 9 & 8 & 3 & 20 \\
\hline & & $\%$ within 2. Belongs to the group: & $0.0 \%$ & $45.0 \%$ & $40.0 \%$ & $100 \%$ & $100 \%$ \\
\hline & & $\begin{array}{l}\% \text { within } 4 . \text { The company in which I work, } \\
\text { has a Code of Ethics? }\end{array}$ & $0.0 \%$ & $17.6 \%$ & $33.3 \%$ & $42.9 \%$ & $24.1 \%$ \\
\hline & \multirow{3}{*}{ Large Company } & count & 0 & 11 & 1 & 1 & 13 \\
\hline & & $\%$ within 2. Belongs to the group: & $0.0 \%$ & $84.6 \%$ & $7.7 \%$ & $7.7 \%$ & $100 \%$ \\
\hline & & $\begin{array}{l}\% \text { within } 4 . \text { The company in which I work, } \\
\text { has a Code of Ethics? }\end{array}$ & $0.0 \%$ & $21.6 \%$ & $4.2 \%$ & $14.3 \%$ & $15.7 \%$ \\
\hline \multirow{3}{*}{\multicolumn{2}{|c|}{ Total }} & count & 1 & 51 & 24 & 7 & 83 \\
\hline & & $\%$ within 2 . Belongs to the group: & $1.2 \%$ & $61.4 \%$ & $28.9 \%$ & $8.4 \%$ & $100 \%$ \\
\hline & & $\begin{array}{l}\% \text { within } 4 . \text { The company in which I work, } \\
\text { has a Code of Ethics? }\end{array}$ & $100 \%$ & $100 \%$ & $100 \%$ & $100 \%$ & $100 \%$ \\
\hline
\end{tabular}

\begin{tabular}{|c|c|c|c|}
\hline Chi-Square Tests & Value & Df & $\begin{array}{c}\text { Asymptotic } \\
\text { Significance (2-sided) }\end{array}$ \\
\hline Pearson Chi-Square & $6.956^{\mathrm{a}}$ & 6 & .325 \\
\hline Likelihood Ratio & 7.879 & 6 & .247 \\
\hline N of Valid Cases & 89 & - & - \\
\hline
\end{tabular}

a. 7 cells $(58.3 \%)$ have expected count less than 5 . The minimum expected count, 16.

\footnotetext{
5 The Chi-Square test tests the hypothesis that two variables are independent of each other's influence. The result show that the type of the company does not has any influence on having a code of ethics.

6 The Chi-Square is calculated using the observed count of variables and expected count of variables (in this case variable is count of answers per questions). By a rule of the thumb, approximately $20 \%$ of cells with an expected count less than 5 are acceptable. In this case the statistic result cannot be considered as reliable.
} 
Attachment 3. Applying the code of ethics to the size of the company

\begin{tabular}{|c|c|c|c|c|c|c|c|}
\hline \multirow{2}{*}{\multicolumn{3}{|c|}{$\begin{array}{l}\text { 2. It falls into the group: * } 4 \text {. Are you following the } \\
\text { principles of the Code of Ethics for professional } \\
\text { accountants when performing accounting jobs: } \\
\text { Crosstabulation }\end{array}$}} & \multicolumn{4}{|c|}{$\begin{array}{l}\text { 4. Do you comply with the principles } \\
\text { of the Code of Ethics for } \\
\text { Professionals accountants in the } \\
\text { course of carrying out accounting } \\
\text { work: }\end{array}$} & \multirow[t]{2}{*}{ Total } \\
\hline & & & $\begin{array}{c}\text { No } \\
\text { answer }\end{array}$ & Yes & Partly & No & \\
\hline \multirow{9}{*}{ 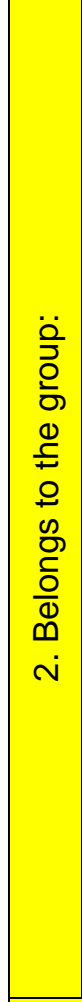 } & \multirow[b]{3}{*}{$\begin{array}{c}\text { Small } \\
\text { Company }\end{array}$} & count & 1 & 40 & 8 & 1 & 50 \\
\hline & & $\%$ within 2 . Belongs to the group: & $2.0 \%$ & $80.0 \%$ & $16.0 \%$ & $2.0 \%$ & $100 \%$ \\
\hline & & $\begin{array}{l}\% \text { within } 4 \text {. Do you comply with the } \\
\text { principles of the Code of Ethics for } \\
\text { Professionals accountants in the } \\
\text { course of carrying out accounting } \\
\text { work }\end{array}$ & $50.0 \%$ & $60.6 \%$ & $61.5 \%$ & $50.0 \%$ & $60.2 \%$ \\
\hline & \multirow[b]{3}{*}{$\begin{array}{l}\text { Medium } \\
\text { Company }\end{array}$} & count & 1 & 15 & 3 & 1 & 20 \\
\hline & & $\%$ within 2 . Belongs to the group: & $5.0 \%$ & $75.0 \%$ & $15.0 \%$ & $5.0 \%$ & $100 \%$ \\
\hline & & $\begin{array}{l}\% \text { within } 4 \text {. Do you comply with the } \\
\text { principles of the Code of Ethics for } \\
\text { Professionals accountants in the } \\
\text { course of carrying out accounting } \\
\text { work }\end{array}$ & $50.0 \%$ & $22.7 \%$ & $23.1 \%$ & $50.0 \%$ & $24.1 \%$ \\
\hline & \multirow[b]{3}{*}{$\begin{array}{l}\text { Large } \\
\text { Company }\end{array}$} & count & 0 & 11 & 2 & 0 & 13 \\
\hline & & $\%$ within 2 . Belongs to the group: & $0.0 \%$ & $84.6 \%$ & $15.4 \%$ & $0.0 \%$ & $100 \%$ \\
\hline & & $\begin{array}{l}\% \text { within } 4 \text {. Do you comply with the } \\
\text { principles of the Code of Ethics for } \\
\text { Professionals accountants in the } \\
\text { course of carrying out accounting } \\
\text { work }\end{array}$ & $0.0 \%$ & $16.7 \%$ & $15.4 \%$ & $0.0 \%$ & $15.7 \%$ \\
\hline \multirow{3}{*}{\multicolumn{2}{|c|}{ Total }} & count & 2 & 66 & 13 & 2 & 83 \\
\hline & & $\%$ within 2 . Belongs to the group & $2.4 \%$ & $79.5 \%$ & $15.7 \%$ & $2.4 \%$ & $100 \%$ \\
\hline & & $\begin{array}{l}\% \text { within } 4 \text {. Do you comply with the } \\
\text { principles of the Code of Ethics for } \\
\text { Professionals accountants in the } \\
\text { course of carrying out accounting } \\
\text { work }\end{array}$ & $100 \%$ & $100 \%$ & $100 \%$ & $100 \%$ & $100 \%$ \\
\hline
\end{tabular}

\begin{tabular}{|c|c|c|c|}
\hline Chi-Square Tests & Value & Df & $\begin{array}{c}\text { Asymptotic } \\
\text { Signifiance (2-sided) }\end{array}$ \\
\hline Pearson Chi-Square & $1.915^{\mathrm{a}}$ & 6 & .927 \\
\hline Likelihood Ratio & 2.280 & 6 & .892 \\
\hline $\mathrm{N}$ of Valid Cases & 83 & & - \\
\hline
\end{tabular}

a. 8 cells $(66.7 \%)$ have expected count less than 5 . The minimum expected count, 31 .

Received for publication:

Revision received:

Accepted for publication:
29.08.2017

04.03 .2018

07.06 .2018 


\section{How to cite this article?}

Style - APA Sixth Edition:

Todorovic, Z. (2018, July 15). Application of the Ethics Code and Rules of Professional Conduct of Accounts and Auditors. (Z. Cekerevac, Ed.) MEST Journal, 6(2), 135-149. doi:10.12709/mest.06.06.02.17

Style - Chicago Sixteenth Edition:

Todorovic, Zoran. 2018. "Application of the Ethics Code and Rules of Professional Conduct of Accounts and Auditors." Edited by Zoran Cekerevac. MEST Journal (MESTE) 6 (2): 135-149. doi:10.12709/mest.06.06.02.17.

Style - GOST Name Sort:

Todorovic Zoran Application of the Ethics Code and Rules of Professional Conduct of Accounts and Auditors [Journal] // MEST Journal / ed. Cekerevac Zoran. - Toronto : MESTE, July 15, 2018. - 2 : Vol. 6. - pp. 135-149.

Style - Harvard Anglia:

Todorovic, Z., 2018. Application of the Ethics Code and Rules of Professional Conduct of Accounts and Auditors. MEST Journal, 15 July, 6(2), pp. 135-149.

Style - ISO 690 Numerical Reference:

Application of the Ethics Code and Rules of Professional Conduct of Accounts and Auditors. Todorovic, Zoran. [ed.] Zoran Cekerevac. 2, Toronto : MESTE, July 15, 2018, MEST Journal, Vol. 6, pp. 135-149. 